\title{
Pengaruh Efikasi Diri terhadap Perilaku Menyontek Siswa Sekolah Dasar selama Pembelajaran Daring
}

\author{
Anitasari, Olivia Pandansari, Rika Susanti*, Kurniawati, \& Abdul Aziz* \\ Fakultas Ilmu Pendidikan, Universitas Negeri Yogyakarta* \\ Jalan Colombo No. 1, Karangmalang, Yogyakarta, 55281, Indonesia \\ Fakultas Keguruan dan Ilmu Pendidikan, Universitas Negeri Sebelas Maret* \\ *Corresponding Author. e-mail: rikasusanti.2018@ student.uny.ac.id
}

\begin{abstract}
Abstrak
Rendahnya efikasi diri pada siswa dapat mendorong terjadinya perilaku tidak terpuji seperti perilaku menyontek. Sedangkan efikasi diri yang tinggi memungkinkan siswa menjadi pribadi yang mampu menyelesaikan semua tugas sekolah dengan usaha dan kemampuan yang dimiliki. Penelitian ini bertujuan untuk mengetahui pengaruh efikasi diri terhadap perilaku menyontek siswa sekolah dasar selama pembelajaran daring. Penelitian ini menggunakan pendekatan penelitian kuantitatif dengan jenis ex-post facto. Populasi pada penelitian ini ialah siswa SD Negeri Talkondo Poncosari, Srandakan, Bantul kelas IV, V, dan VI. Penelitian ini melibatkan seluruh populasi dengan jumlah 45 siswa. Data dikumpulkan dengan menggunakan skala efikasi diri dan skala perilaku menyontek. Selanjutnya, data dianalisis menggunakan analisis regresi sederhana dengan bantuan SPSS 24.0. Hasil penelitian menunjukan bahwa efikasi diri berpengaruh negatif terhadap perilaku menyontek siswa. Dalam penelitian ini, efikasi diri memberikan pengaruh sebesar 23,9\% terhadap perilaku menyontek siswa, sedangkan sisanya dipengaruhi oleh faktor lain. Berdasarkan hasil penelitian tersebut, guru dan orang tua perlu melakukan berbagai upaya untuk meminimalisir terjadinya perilaku menyontek, khususnya saat pembelajaran daring seperti saat ini.
\end{abstract}

Kata Kunci: efikasi diri, perilaku menyontek, pembelajaran daring

\section{The Effect of Self-Efficacy towards Cheating Behavior of Elementary School Student during Online Learning}

\begin{abstract}
Low self-efficacy in students can encourage the occurrence of disgraceful behavior such as cheating behavior. While high self-efficacy enables students to become persons who can complete all of the school assignments with their efforts and abilities that they have. The purpose of this research is to find out the effect of self-efficacy on the cheating behavior of elementary school students during online learning. This research uses a quantitative research approach with a type of ex-post-facto. The population in this research are students of Talkondo Poncosari State Elementary School Srandakan, Bantul in IV, V, and VI grades. This research implicates the entire population with a total of 45 students. Data are collected by using the scale of self-efficacy and the scale of cheating behavior. Furthermore, the data are analyzed by using simple regression analysis with the help of SPSS 24.0. The result of the research shows that selfefficacy has a negative effect on students' cheating behavior. In this research, self-efficacy provides an effect of 23.9\% towards students' cheating behavior, while the remainder is affected by other factors. Based on the result of the research, teachers and parents need to make various efforts to minimize the occurrence of cheating behavior, particularly during online learning as of today.
\end{abstract}

Keywords: self-efficacy, cheating behavior, online learning

How to Cite: Anitasari, Pandansari, O., Susanti, R., Kurniawati, \& Aziz, A. (2021). Pengaruh efikasi diri terhadap perilaku menyontek siswa sekolah dasar selama pembelajaran daring. Jurnal Penelitian Ilmu Pendidikan, 14(1), 82-90. doi:https://doi.org/10.21831/jpipfip.v14i1.37661.

Received 11-01-2021; Received in revised from 06-02-2021; Accepted 25-02-2021

This is an open-access article under the CC-BY-SA license. 
Jurnal Penelitian Ilmu Pendidikan, 14 (1), 2021 - 83

Anitasari, Pandansari, Susanti, Kurniawati \& Aziz

\section{PENDAHULUAN}

Pandemi Covid-19 telah membawa perubahan yang besar dalam berbagai dimensi kehidupan manusia, tidak terkecuali dalam dunia pendidikan. Berbagai upaya telah pemerintah lakukan demi memperkecil kasus penularan Covid-19. SE Mendikbud No. 4 Tahun 2020 menjelaskan mengenai beberapa peraturan pemerintah dalam rangka mencegah kasus penularan Covid-19 di sekolah-sekolah. Salah satunya yaitu kebijakan mengenai proses belajar dari rumah. Dijelaskan bahwa pemberian pengalaman belajar yang bermakna bagi siswa merupakan tujuan pembelajaran daring dimasa Covid - 19 (Surat Edaran Mendikbud No 4 Tahun 2020).

Melalui pembelajaran daring siswa dituntut untuk memiliki kemandirian belajar dan keyakinan diri pada kemampuannya masing-masing. Keyakinan diri pada kemampuan inilah yang dikenal dengan istilah self efficacy atau efikasi diri. Latifah (2018) berpendapat bahwa efikasi diri merupakan kemampuan seseorang dalam melakukan pengelolaan situasi dengan cara meyakinkan dirinya bahwa ia mampu mengatur dan melaksanakan tindakan yang tepat. Priaswandy (2015:3) menyataan bahwa efikasi diri merupakan kepercayaan atau keyakinan siswa bahwa ia mampu menyelesaikan tugas yang ia dihadapi dan mampu melaksanakan Ujian Tengah Semester atau Ujian Akhir Semester, sehingga mampu mendapatkan nilai yang memuaskan dan mencapai tujuan yang ia harapkan. Efikasi diri yang tinggi dan perilaku pengaturan diri yang positif adalah prediktor yang dapat diandalkan untuk keberhasilan akademis dalam pembelajaran daring (Landrum, 2020). Oleh karenanya, efikasi diri sangat dibutuhkan selama pembelajaran dari rumah.

Namun, pada pelaksanaannya ternyata masih banyak ditemukan siswa yang tidak memiliki kepercayaan diri terhadap kemampuannya masing-masing sehingga berbagai cara dilakukan agar mendapatkan nilai atau hasil yang terbaik. Kecurangan sudah menjadi masalah global yang ada di mana-mana. Salah satu kecurangan tersebut yaitu menyontek. Manoppo \& Mardapi (2014:118) mendefinisikan menyontek atau cheating sebagai segala cara atau usaha mencapai keberhasilan dalam menyelesaikan tugas-tugas akademik terutama saat evaluasi/ujian hasil dengan cara yang tidak terpuji atau berbuat curang yang mengabaikan aturan dan kesepakatan yang ada. Webster's New Universal Unabridged Dictionary (Schmelkin, Gilbert, Spencer, Pincus, \& Silva, 2008) menyampaikan bahwa menyontek diartikan sebagai perilaku yang menipu yaitu dengan kecurangan. Hal ini sependapat dengan Kusrieni (2014) yang juga menyatakan bahwa mencontek adalah perilaku yang termasuk dalam kategori kecurangan akademik yang dilakukan seseorang dengan cara-cara yang tidak jujur demi mendapatkan keberhasilan. Hamdani (2014:76) menyebutkan faktor penyebab terjadinya perilaku menyontek ialah: 1) tidak mengerti dengan pelajaran yang disampaikan; 2) rasa malas untuk belajar; 3) berorientasi pada nilai; 4) pengaruh teman dan lingkungan. Orientasi nilai atau tujuan untuk mendapatkan prestasi belajar yang baik menjadi salah satu alasan kuat kenapa tindakan menyontek dilakukan (Anderman \& Koenka, 2017).

Dalam dunia pendidikan, perilaku menyontek memang bukan hal yang baru. Banyak penelitian sudah membuktikan bahwa perilaku menyontek telah berkembang di berbagai kalangan, mulai dari tingkat pendidikan sekolah dasar hingga perguruan tinggi. Dalam penelitian yang dilakukan oleh Cizek (Lusiane \& Garvin, 2018) disebutkan bahwa sepertiga dari usia siswa SD melakukan kecurangan akademik atau menyontek. Hal tersebut juga didukung oleh hasil penelitian Hariandi (2020:62) yang mengatakan bahwa penyebab siswa melakukan perilaku curang ketika ujian adalah faktor lingkungan. Faktor lingkungan atau situasi yang mendukung untuk berbuat curang, contohnya ketika pengawas keluar dari ruangan ujian atau minimnya pengawasan ketika ujian berlangsung. Jika dalam pembelajaran konvensional saja siswa sudah berani melakukan kecurangan atau menyontek, lalu bagaimana dengan pembelajaran daring yang dalam hal ini guru tidak bisa mengawasi siswanya secara langsung. Selama pembelajaran daring kesempatan siswa untuk berbuat curang lebih besar (Watson \& Sottile, 2010). Dalam penelitian yang dilakukan oleh King (2014) diungkapkan bahwa selama ujian dilaksanakan dari rumah, siswa akan merasa lebih mudah untuk melakukan tindakan tidak etis seperti menyontek saat mengerjakan pekerjaan rumah, menyontek saat ujian, menyontek dalam pembuatan makalah, dan menyontek saat mengerjakan proyek internet.

Perilaku menyontek merupakan salah satu perbuatan yang harus diberantas, terutama dalam dunia pendidikan. Perilaku yang awalnya dianggap sepele ini jika tidak diberantas sedini mungkin 
maka akan membawa dampak besar bagi kehidupan masyarakat. Perilaku menyontek yang dilakukan berkelanjutan akan menanamkan kebiasaan untuk berbuat tidak jujur, yang nantinya akan melahirkan calon-calon koruptor. Meningkatkan efikasi diri dalam diri masing-masing siswa merupakan salah satu cara untuk mengurangi kasus menyontek. Efikasi diri yang tinggi akan mendorong siswa untuk selalu bersikap jujur dan baik selama pembelajaran daring. Hal tersebut sesuai dengan hasil penelitian Purwanto (2015) yang menyatakan bahwa efikasi diri berpengaruh atau berhubungan negatif terhadap perilaku menyontek. Semakin tinggi efikasi diri siswa maka semakin rendah tingkat perilaku menyontek siswa, begitupun sebaliknya.

Berdasarkan uraian yang telah dikemukakan di atas, maka yang menjadi permasalahan peneliti dalam penelitian ini adalah "apakah efikasi diri mempengaruhi perilaku menyontek siswa sekolah dasar selama pembelajaran daring?". Dengan demikian, tujuan dari penelitian ini adalah untuk mengetahui ada atau tidaknya pengaruh efikasi diri terhadap perilaku menyontek siswa sekolah dasar selama pembelajaran daring dan seberapa besar pengaruhnya sekaligus menjawab rumusan masalah dari penelitian ini.

\section{METODE}

Penelitian ini merupakan penelitian survei kuantitatif dengan jenis penelitian ex-post facto yang bertujuan untuk meneliti ada atau tidaknya pengaruh efikasi diri terhadap perilaku menyontek siswa SD. Penelitian ini dilakukan di SD Negeri Talkondo, Poncosari, Srandakan, Bantul, D.I. Yogyakarta. Populasi dalam penelitian ini adalah siswa kelas tinggi di SD Negeri Talkondo tahun ajaran 2020/2021. Teknik pengambilan sampel menggunakan teknik sampel jenuh karena jumlah populasi yang relatif sedikit. Oleh karena itu peneliti menggunakan seluruh populasi yang berjumlah 45 orang sebagai sampel dalam penelitian ini yang terdiri dari 22 siswa laki-laki dan 23 siswa perempuan. Jumlah populasi tersebut merupakan gabungan dari siswa kelas IV sejumlah 6 orang (4 laki-laki, 2 perempuan), siswa kelas $\mathrm{V}$ sejumlah 18 orang (9 laki-laki, 9 perempuan), dan siswa kelas VI sejumlah 21 orang (9 laki-laki, 12 perempuan).

Pengumpulan data dalam penelitian ini menggunakan skala psikologi yang disebarkan dan diisi secara langsung (offline) oleh sampel penelitian. Skala psikologi yang digunakan dalam instrumen penelitian ini diadposi dari instrumen penelitian yang dilakukan oleh Purwanto (2015). Data yang telah terkumpul, selanjutnya dianalisis menggunakan statistik deskriptif dan regresi sederhana dengan bantuan SPSS 24.0.

Setelah diperoleh data mengenai efikasi diri dan perilaku menyontek siswa, selanjutnya dilakukan penggolongan subjek menjadi tiga kategori yaitu rendah, sedang, tinggi. Pengkategorian data penelitian ini menggunakan rumus yang disampaikan oleh Azwar (Purwaningsih \& Herwin, 2020:24) sebagai berikut.

Tabel 1. Pengkategorian Data Penelitian

\begin{tabular}{cc}
\hline Nilai & Kategori \\
\hline Mean $+1 \mathrm{SD} \leq \mathrm{X}$ & Tinggi \\
Mean $-1 \mathrm{SD} \leq \mathrm{X}<$ Mean $+1 \mathrm{SD}$ & Sedang \\
$\mathrm{X}<$ Mean $-1 \mathrm{SD}$ & Rendah \\
\hline
\end{tabular}

\section{HASIL DAN PEMBAHASAN}

\section{Hasil}

\section{Analisis Deskriptif Variabel Efikasi Diri}

Pada variabel efikasi diri data diperoleh dari 45 siswa menggunakan skala penilaian efikasi diri siswa. Setelah dilakukan pengambilan data, maka dapat disajikan deskripsi data ukuran kecenderungan memusat yaitu mean, modus dan median serta ukuran keragaman yaitu, standar deviation, variance, skor maksimal, dan skor minimal, dan dalam tabel berikut. 
Jurnal Penelitian Ilmu Pendidikan, 14 (1), 2021 - 85

Anitasari, Pandansari, Susanti, Kurniawati \& Aziz

Tabel 2. Statistik Deskriptif Variabel Efikasi Diri

\begin{tabular}{ll}
\hline Statistik & Koefisien \\
\hline Mean & 77.489 \\
Median & 77.000 \\
Mode & 77.00 \\
Std. Deviation & 9.147 \\
Variance & 83.665 \\
Maximum & 97 \\
Minimum & 58 \\
\hline
\end{tabular}

Berdasarkan tabel 2 tersebut, diketahui bahwa sebaran skor efikasi diri siswa bergerak antara 58 sebagai skor terendah hingga 97 sebagai skor tertinggi. Adapun varian data sebesar 83,665 dengan simpangan baku sebesar 9,147. Selain itu, rata-rata skor diperoleh sebesar 77,489 dengan modus 77 dan median 77. Sesuai data tersebut, kemudian disajikan pengkategorian efikasi diri siswa untuk mengetahui kecenderungan efikasi diri siswa berdasarkan data yang ada sebagai berikut.

Tabel 3. Sebaran data efikasi diri siswa berdasarkan pengkategorian skor

\begin{tabular}{lccc}
\hline \multicolumn{1}{c}{ Interval } & Kategori & Frekuensi & Persentase \\
\hline Tinggi & $\mathrm{X} \geq 86,6$ & 7 & $15,5 \%$ \\
Sedang & $68,3 \leq \mathrm{X}<86,6$ & 31 & $69 \%$ \\
Rendah & $\mathrm{X}<68,3$ & 7 & $15,5 \%$ \\
\hline \multicolumn{4}{r}{} \\
\hline
\end{tabular}

Berdasarkan tabel 3 tersebut, diketahui bahwa sebanyak 15,5\% atau 7 siswa tergolong efikasi diri rendah, $69 \%$ atau 31 orang siswa tergolong memiliki efikasi diri sedang sedangkan $15,5 \%$ atau 7 siswa memiliki efikasi diri tinggi. Jika ditinjau berdasarkan skor rata-rata yang telah diperoleh sebelumnya yaitu 77,489 maka dapat dikemukakan bahwa tingkat efikasi diri siswa berada pada kategori sedang.

\section{Analisis Deskriptif Variabel Perilaku Menyontek}

Pada variabel perilaku menyontek data diperoleh dari 45 siswa menggunakan skala penilaian perilaku menyontek siswa. Setelah dilakukan pengambilan data, maka dapat disajikan deskripsi data ukuran kecenderungan memusat yang meliputi nilai rata-rata, nilai tengah, dan modus, serta ukuran keragaman yaitu standar deviasi, varian, skor maksimal dan skor minimal dalam tabel berikut.

Berdasarkan tabel 4, diketahui bahwa sebaran skor perilaku menyontek siswa bergerak antara 32 sebagai skor terendah hingga 80 sebagai skor tertinggi. Adapun varian data sebesar 148,364 dengan simpangan baku sebesar 12,180. Selain itu, rata-rata skor diperoleh sebesar 58,333 dengan modus 60 dan median 60.

Tabel 4. Statistik Deskriptif Variabel Perilaku Menyontek

\begin{tabular}{ll}
\hline Statistik & Koefisien \\
\hline Mean & 58.333 \\
Median & 60.0000 \\
Mode & 60.00 \\
Std. Deviation & 12.180 \\
Variance & 148.364 \\
Maximum & 32 \\
Minimum & 80 \\
\hline
\end{tabular}

Sesuai data tersebut, kemudian disajikan pengkategorian perilaku menyontek siswa untuk mengetahui kecenderungan perilaku menyontek siswa berdasarkan data yang ada sebagai berikut.

Tabel 5. Sebaran Data Perilaku Menyontek Siswa Berdasarkan Pengkategorian Skor

\begin{tabular}{lccc}
\hline \multicolumn{1}{c}{ Interval } & Kategori & Frekuensi & Persentase \\
\hline Tinggi & $\mathrm{X} \geq 70,5$ & 7 & $15,5 \%$ \\
Sedang & $46,1 \leq X<70,5$ & 31 & $69 \%$ \\
Rendah & $X<46,1$ & 7 & $15,5 \%$ \\
\hline & Total & & $\mathbf{1 0 0 \%}$ \\
\hline
\end{tabular}


Berdasarkan tabel 5 tersebut, diketahui bahwa sebanyak 15,5\% atau 7 siswa tergolong rendah dalam berperilaku menyontek, $69 \%$ atau 31 orang siswa tergolong sedang dalam berperilaku menyontek, sedangkan $15,5 \%$ atau 7 siswa tergolong tinggi dalam berperilaku menyontek. Jika ditinjau berdasarkan skor rata - rata yang telah diperoleh sebelumnya yaitu 58,333 maka dapat dikemukakan bahwa tingkat berperilaku menyontek siswa berada pada kategori sedang.

\section{Pengujian Hipotesis}

Pengujian hipotesis bertujuan untuk mengetahui pengaruh variabel efikasi diri terhadap variabel perilaku menyontek. Perhitungan uji hipotesis menggunakan analisis regresi sederhana dengan menggunakan bantuan SPSS 24.0. Setelah dilakukannya perhitungan dengan menggunakan bantuan SPSS 24.0 didapatkan hasil pengujian hipotesis yaitu :

Tabel 6. Hasil Uji Regresi Sederhana Model Summary

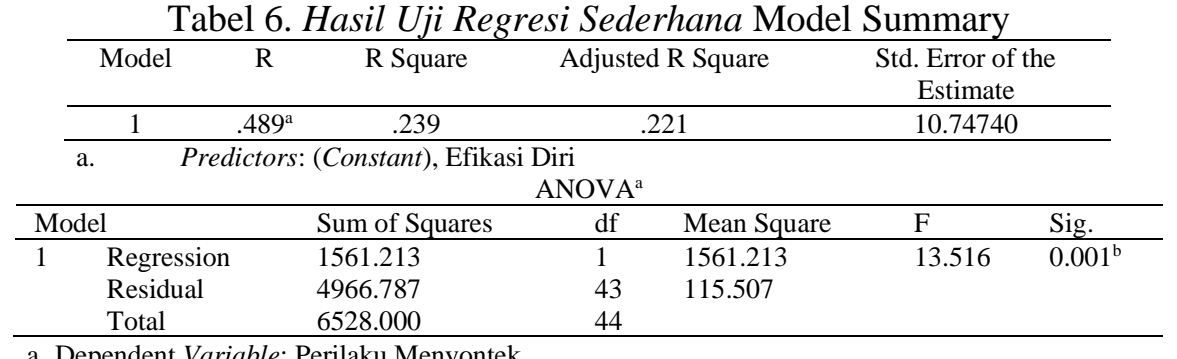

a. Dependent Variable: Perilaku Menyontek

b. Predictors: (Constant), Efikasi Diri

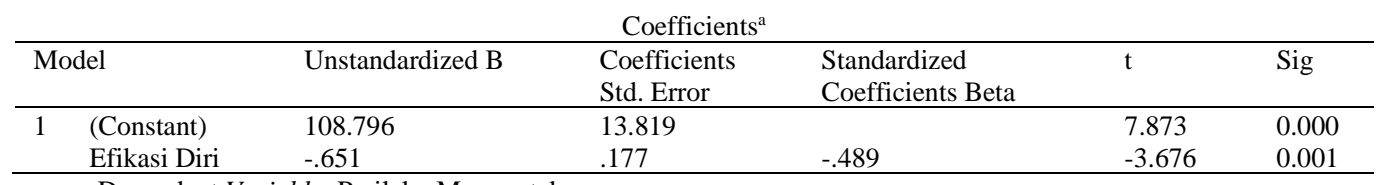

a. Dependent Variable: Perilaku Menyontek

Besarnya pengaruh (sumbangan efektif) antara seluruh variabel independen terhadap variabel dependen ditunjukkan pada nilai $\mathrm{R}^{2}$. Dari tabel 6 besarnya $\mathrm{R}^{2}$ yang dihasilkan 0,239 artinya sebesar $23,9 \%$ variasi perilaku menyontek dipengaruhi oleh variabel efikasi diri sedangkan sisanya $76,1 \%$ dipengaruhi oleh faktor yang lain. Selanjutnya dilakukan uji F untuk mendeteksi adanya kecocokan model yang menghasilkan $\mathrm{F}$ hitung sebesar 13,516 dengan signifikansi sebesar 0,001. Model regresi yang dihasilkan dapat dikatakan cocok untuk digunakan karena signifikansi 0,001 <0,05.

Untuk mengetahui pengaruh parsial antara variabel independen terhadap variabel dependent dapat dilihat dari hasil uji t pada regresi ini. Dari tabel 6 menunjukkan nilai koefisien beta yang negatif yaitu $-0,489$ sehingga dapat dikatakan bahwa pengaruh yang ditimbulkan dalam penelitian ini bersifat negatif. Selanjutnya dengan membandingkan nilai sig $=0,001<\operatorname{taraf}$ kesalahan $5 \%=0,05$ maka dapat disimpulkan bahwa efikasi diri berpengaruh negatif signifikan terdapat perilaku mencontek. Berdasarkan pada pengujian hipotesis di atas peneliti menyimpulkan bahwa efikasi diri berpengaruh negatif dan signifikan terhadap perilaku menyontek siswa kelas tinggi SDN Talkondo tahun ajaran 2020/2021.

\section{Pembahasan}

Pada variabel efikasi diri analisis statistik menunjukkan bahwa sebanyak 69\% dari 40 siswa memiliki tingkat efikasi diri yang sedang, sedangkan siswa dengan tingkat efikasi diri yang termasuk dalam kategori tinggi dan rendah memiliki jumlah yang sama yaitu sebanyak 15,5\%. Maka, jika ditinjau berdasarkan skor rata-rata yang telah diperoleh dari sebaran data efikasi diri siswa yaitu 77,489 maka dapat disimpulkan bahwa tingkat efikasi diri siswa berada pada kategori sedang.

Efikasi diri merupakan merupakan evaluasi individu atas kemampuannya sendiri untuk mencapai tujuan atau kepercayaan diri untuk melakukannya (Yokoyama, 2019). Efikasi diri tentu saja tergantung dengan situasi akademik, dapat diasumsikan bahwa peserta didik yang memiliki efikasi diri tinggi memiliki motivasi belajar yang lebih tinggi sehingga prestasi akademiknya akan semakin 
tinggi, karena peserta didik tersebut yakin bahwa ia memiliki kemampuan untuk mencapai tujuannya. Hasil penelitian menunjukkan bahwa efikasi diri siswa dalam kategori sedang, dengan persentase 69\%. Hal ini menunjukkan bahwa efikasi diri siswa dalam pembelajaran daring berkaitan dengan kinerja atau situasi akademik dalam lingkungan pembelajaran daring (Hampton et al., 2020). Efikasi diri siswa dalam pembelajaran daring sedang, hal ini karena dipengaruhi oleh sikap peserta didik terhadap instruksi daring atau keakraban dengan perangkat pembelajaran daring (Cussó-Calabuig, Farran, \& Bosch-Capblanch, 2018). Faktor lain berasal dari karakteristik siswa dan perbedaan antara kelas dan pembelajaran daring. Misalnya, instruksi daring berbasis tugas dan yang memotivasi siswa dalam memiliki orientasi tugas (Yokoyama, 2019).

Sedangkan pada variabel perilaku menyontek, analisis statistik menunjukkan bahwa sebanyak 69\% dari 40 siswa memiliki tingkat perilaku menyontek yang sedang, kemudian siswa dengan tingkat perilaku menyontek yang termasuk dalam kategori tinggi dan rendah memiliki jumlah yang sama yaitu sebanyak 15,5\%. Jika ditinjau berdasarkan skor rata - rata yang telah diperoleh dari sebaran data perilaku menyontek yaitu 58,333, maka dapat disimpulkan bahwa tingkat berperilaku menyontek siswa berada pada kategori sedang.

Berdasarkan data perilaku menyontek siswa selama pembelajaran daring menunjukkan bahwa tingkat ketidakjujuran siswa dalam kategori sedang. Namun, $69 \%$ persen siswa menyontek bukanlah angka yang dapat diabaikan begitu saja. Ketidakjujuran siswa selama pembelajaran daring dapat dijelaskan terkait dengan interaksi sosial dalam kelas langsung berperan dalam menentukan apakah siswa memutuskan untuk menyontek (Watson \& Sottile, 2010). Keakraban dengan sesama siswa dapat mengurangi keberatan moral terhadap kecurangan saat mereka mengerjakan tugas dan penilaian bersama selama masa sekolah. Siswa akan lebih banyak menyontek dalam kursus daring daripada di ruang kelas biasa (King, Guyette, \& Piotrowski, 2009).

Data di atas menunjukan bahwa responden memiliki kepercayaan dan keyakinan diri yang ada pada dirinya sehingga memiliki tingkat tindak perilaku menyontek yang juga tergolong sedang. Tingkat efikasi diri berperan terhadap perilaku menyontek. Siswa harus percaya bahwa mereka dapat menerapkan pengetahuan atau keterampilan yang mereka miliki pada berbagai situasi, mereka perlu memiliki efikasi diri yang tinggi untuk self-regulated learning (Putarek \& Pavlin-Bernardić, 2019). Semakin tinggi efikasi diri maka cenderung untuk tidak menyontek, sebaliknya semakin rendah efikasi diri akan berpengaruh pada rendahnya motivasi untuk giat belajar, mengerjakan tugas, sehingga membuat seseorang menyontek (Finn \& Frone, 2004). Penelitian lain yang melihat hubungan antara efikasi diri dengan perilaku menyontek adalah penelitian yang dilakukan oleh Finn \& Frone (Sieman, 2009) yang menyatakan bahwa identifikasi interaksi variabel efiaksi diri dalam hubungannya dengan perilaku menyontek. Identifikasi tersebut yaitu efikasi diri yang rendah sangat berpengaruh pada perilaku menyontek.

Pada pengujian hipotesis yang telah dilakukan didapatkan hasil bahwa nilai koefisien beta yang negatif sebesar $-0,489$ dan nilai sig $=0,001<$ taraf kesalahan $5 \%=0,05$. Hasil tersebut memiliki arti bahwa efikasi diri berpengaruh negatif dan signifikan terhadap perilaku menyontek. Setiap peningkatan efikasi diri yang terjadi akan berpengaruh negatif terhadap perilaku menyontek, dengan kata lain efikasi diri yang meningkat akan membuat perilaku menyontek turun. Hal ini sesuai dengan penelitian yang telah dilakukan oleh (Kusrieni, 2014) yang hasilnya menyebutkan bahwa siswa yang memiliki tingkat efikasi diri yang tinggi akan enggan menyontek atau menunjukkan perilaku mencontek yang rendah dibandingkan dengan siswa yang memiliki tingkat efikasi diri yang lebih rendah. Dalam penelitian yang telah dilakukan oleh Erawati (2015:63) juga diperoleh kesimpulan yang menyatakan bahwa apabila skor efikasi seseorang rendah maka semakin tinggi perilaku menyontek, begitu juga sebaliknya. Jadi, tingkat efikasi diri yang dimiliki siswa berpengaruh negatif dan signifikan terhadap perilaku menyontek siswa.

Widyaninggar (2015:98) anak yang memiliki efikasi diri yang tinggi akan menunjukkan ciri ciri sebagai berikut yaitu: 1) memiliki rasa percaya diri yang tinggi, 2) memiliki rasa ingin tahu yang tinggi, 3) mau mempelajari materi yang belum diajarkan guru sebelum disuruh, 4) memiliki trik atau cara khusus dalam menyelesaikan suatu soal atau masalah, dan 5) tidak malu untuk bertanya. Perilaku menyontek akan cenderung berkurang jika efikasi diri siswa meningkat. Berdasarkan penelitian Mc Cabe, dkk (Salami, 2010) bahwa efikasi diri dapat digunakan untuk mengurangi perilaku menyontek hal ini berdasarkan pengertian bahwa individu dengan efikasi diri yang tinggi, merasa 
bahwa ia mampu untuk melakukan tugas yang diberikan serta memiliki keyakinan bahwa ia mampu untuk menyelesaikannya dengan baik. Sebaliknya, perilaku menyontek akan cenderung meningkat jika efikasi diri siswa menurun. Karena siswa yang memiliki efikasi diri yang rendah akan merasa ragu dan tidak ada semangat dalam mengerjakan tugas. Oleh karena itu, diharapkan dapat meningkatkan efikasi dirinya sehingga memiliki keyakinan akan kemampuan dirinya, dapat membuat keputusan yang baik untuk yakin percaya diri dalam menyelesaikan tugas tanpa perlu meyakinkan diri dahulu dengan melihat pekerjaan orang lain.

Pada perhitungan uji hipotesis menunjukkan bahwa indeks determinasi $\left(\mathrm{R}^{2}\right)$ adalah sebesar 0,239. Angka tersebut menunjukkan besarnya pengaruh variabel efikasi diri terhadap variabel perilaku menyontek. Nilai $\left(\mathrm{R}^{2}\right)$ sebesar 0,239 menunjukan bahwa efikasi diri hanya memberikan pengaruh sebesar 23,9\% terhadap perilaku menyontek sedangkan sisanya sebesar 76,1\% dipengaruhi oleh faktor lain. Efikasi diri bukanlah satu - satunya penyebab terjadinya perilaku meyontek. Terdapat faktorfaktor lain yang dapat menjadi pendorong terjadinya perilaku menyontek. Kurniasih, Limbong, \& Handayani (2019) membagi faktor pendorong terjadinya perilaku menyontek menjadi dua jenis, yaitu faktor internal dan faktor eksternal. Faktor Internal tersebut diantaranya: perasaan tidak mampu, tidak suka terhadap mata pelajaran, pemikiran "yang penting lulus", tidak percaya diri kepada kemampuannya, perasaan takut, khawatir, malas, dan ingin mendapatkan pujian. Sedangkan faktor eksternal luar yang dapat menimbukan faktor internal antara lain: soal yang susah atau pelajaran yang susah dipahami, pengatuh teman, keadaan/situasi, pengawas yang kurang disiplin/tegas, tekanan, tuntutan dari keluarga. Banyak faktor individu yang mempengaruhi perilaku menyontek, menunjukkan bahwa karakteristik demografis; kualitas karakter (misalnya, kurangnya pengendalian diri, tujuan hidup yang berorientasi pada orang lain), pengalaman belajar, dan persepsi dan sikap siswa semuanya secara signifikan terkait dengan kecurangan akademik atau menyontek (Yu, Glanzer, Sriram, Johnson, \& Moore, 2017). Berdasarkan hasil penelitian dan para pendapat ahli tersebut dapat disimpulkan bahwa efikasi diri bukanlah sebagai penyebab atau faktor utama pada perilaku menyontek. Selain tingkat efikasi diri yang rendah, masih terdapat beberapa penyebab atau faktor lain yang dapat mempengaruhi perilaku menyontek siswa. Jadi, efikasi diri hanyalah salah satu faktor yang dapat mempengaruhi perilaku menyontek. Perlu diperhatikan juga faktor atau penyebab lain yang memungkinkan siswa menjadi terdorong untuk tidak melakukan perilaku menyontek agar perilaku menyontek pada siswa berkurang dengan efektif. Faktor lain tersebut antara lain pengawasan, dorongan, motivasi dari orang tua dan guru.

\section{PENUTUP}

Efikasi diri mempunyai pengaruh negatif terhadap perilaku menyontek. Perilaku menyontek akan cenderung berkurang jika efikasi diri siswa meningkat. Karena siswa yang memiliki efikasi diri yang tinggi akan merasa yakin dan berusaha lebih giat dalam mengerjakan tugas dengan baik. Sebaliknya, perilaku menyontek akan cenderung meningkat jika efikasi diri siswa menurun. Karena siswa yang memiliki efikasi diri yang rendah akan merasa ragu dan tidak ada semangat dalam mengerjakan tugas. Efikasi diri hanyalah salah satu faktor penyebab yang mempengaruhi perilaku menyontek. Agar pengurangan perilaku menyontek efektif perlu diperhatikan juga faktor atau penyebab lain yang memungkinkan siswa menjadi terdorong untuk tidak melakukan perilaku menyontek seperti peran orang tua dan guru. Pada dasarnya orang tua dan guru menjadi lingkungan utama dalam membantu efikasi diri dan melakukan bimbingan belajar.

\section{UCAPAN TERIMA KASIH}

Penelitian ini adalah bentuk kerjasama antara Universitas Negeri Yogyakarta dan Universitas Sebelas Maret, sehingga tim peneliti berterimakasih telah terfasilitasinya riset ini. Tim peneliti juga mengucapkan terimakasih pada Dr. Yoppy Wahyu Purnomo yang telah memperbaiki draf awal artikel ini dan juga sebagai pakar pendamping untuk penelitian ini. Kami juga berterimakasih kepada partisipan yang terlibat dalam penelitian ini. 
Jurnal Penelitian Ilmu Pendidikan, 14 (1), 2021 - 89

Anitasari, Pandansari, Susanti, Kurniawati \& Aziz

\section{DAFTAR PUSTAKA}

Anderman, E. M., \& Koenka, A. C. (2017). The relation between academic motivation and cheating. theory into practice, 56(2), 95-102. https://doi.org/10.1080/00405841.2017.1308172

Cussó-Calabuig, R., Farran, X. C., \& Bosch-Capblanch, X. (2018). Effects of intensive use of computers in secondary school on gender differences in attitudes towards ICT: A systematic review. Education and Information Technologies, 23(5), 2111-2139. https://doi.org/10.1007/s10639-018-9706-6.

Erawati, M. (2015). Prestasi akademik siswa dalam kaitannya dengan motivasi akademik, persepsi terhadap dukungan akademik dan peran orang tua. Yogyakarta: Universitas Gadjah Mada.

Finn, K. V., \& Frone, M. R. (2004). Academic performance and cheating: Moderating role of school identification and self-efficacy. Journal of Educational Research. https://doi.org/10.3200/JOER.97.3.115-121.

Hamdani, R. U. (2014). Menyontek...? yukk!! hmm...nggak ah!!. Diakses dari Transmedia. https://books.google.co.id/books?hl=id\&lr=\&id=8TR2BAAAQBAJ\&oi=fnd\&pg=PA2\&dq=Me nurut+Hamdani+(2014:+76)+faktor+penyebab+terjadinya+perilaku+menyontek+\&ots=BLBOF AqqzZ\&sig=ZZkahkApmXkkHpEJTtctpjpnnEg\&redir_esc=y\#v=onepage\&q\&f=false .

Hampton, D., Culp-Roche, A., Hensley, A., Wilson, J., Otts, J. A., Thaxton-Wiggins, A., Fruh, S., \& Moser, D. K. (2020). Self-efficacy and satisfaction with teaching in online courses. Nurse Educator, 45(6), 302-306. https://doi.org/10.1097/NNE.0000000000000805.

Hariandi, A. (2020). Implementasi nilai kejujuran akademik peserta didik di lingkungan sekolah dasar. Nur El-Islam: Jurnal Pendidikan dan Sosial Keagamaan, 7(1), 52-66.

King, C. G., Guyette, R. W., \& Piotrowski, C. (2009). Online exams and cheating: An empirical analysis of business students' views. Journal of Educators Online, 6(1), 1-11. https://doi.org/10.9743/JEO.2009.1.5

King, D. L. (2014). E-Cheating: Incidence and trends among college students. Issues in Information Systems, 15(1), 20-27.

Kurniasih, P., Limbong, E. G., \& Handayani, D. (2019). Infografis alasan menyontek dan tipe-tipe penyontek: pandangan etika mengenai perilaku menyontek. Jurnal Desain, 6(02), 112-128. https://doi.org/10.30998/jurnaldesain.v6i2.2969.

Kusrieni, D. (2014). Hubungan efikasi diri dengan perilaku mencontek. PSIKOPEDAGOGIA Jurnal Bimbingan dan Konseling, 3(2), 100-101. https://doi.org/10.12928/psikopedagogia.v3i2.4469.

Landrum, B. (2020). Examining students' confidence to learn online, self-regulation skills and perceptions of satisfaction and usefulness of online classes. Online Learning Journal, 24(3), 128-146. https://doi.org/10.24059/olj.v24i3.2066.

Latifah, A. (2018). Pengaruh konsep diri dan efikasi diri terhadap motivasi berprestasi. Jurnal Pendidikan Guru Sekolah Dasar Edisi 29 Tahun Ke-7 2018, 7(29), 811-821.

Lusiane, L., \& Garvin. (2018). Tekanan orangtua, perfeksionisme, dan ketidakjujuran akademik pada pelajar di Jakarta (Parental pressure, perfectionism, and academical dishonesty among students in Jakarta). Mind Set, 9(1), 60-77.

Manoppo, Y., \& Mardapi, D. (2014). Analisis metode cheating pada tes berskala besar. Jurnal Penelitian dan Evaluasi Pendidikan, 18(1), 115-128. https://doi.org/10.21831/pep.v18i1.2128.

Priaswandy, G. M. (2015). Hubungan antara self efficacy dengan perilaku menyontek pada siswa kelas xi di sma negeri 1 Pleret Bantul Yogyakarta. Jurnal Riset Mahasiswa Bimbingan dan Konseling, 4(6), 1-14.

Purwaningsih, A. Y., \& Herwin, H. (2020). Pengaruh regulasi diri dan kedisiplinan terhadap kemandirian belajar siswa di sekolah dasar. Jurnal Penelitian Ilmu Pendidikan, 13(1), 22-30. https://doi.org/10.21831/jpipfip.v13i1.29662.

Purwanto, A. (2015). Pengaruh efikasi diri terhadap perilaku menyontek siswa kelas v sekolah dasar negeri se-gugus ii kecamatan Pakem kabupaten Sleman tahun ajaran 2014/2015. Fakultas Ilmu Pendidikan. Universitas Negeri Yogyakarta.

Putarek, V., \& Pavlin-Bernardić, N. (2019). The role of self-efficacy for self-regulated learning, achievement goals, and engagement in academic cheating. European Journal of Psychology of Education. https://doi.org/10.1007/s10212-019-00443-7. 
Salami, S. (2010). Emotional intelligence, self-efficacy, psychological well-being and students attitudes: Implications for quality education. European Journal of Educational Studies, 2(3), 247-257. http://www.ozelacademy.com/EJES_v2n3_8.pdf.

Schmelkin, L. P., Gilbert, K., Spencer, K. J., Pincus, H. S., \& Silva, R. (2008). A multidimensional scaling of college students' perceptions of academic dishonesty. Journal of Higher Education, 79(5), 587-607. https://doi.org/10.1353/jhe.0.0021.

Sieman, A. M. (2009). Motivational predictors of academic cheating among first-year college students: goals, expectations, and costs. North Carolina State University.

SE Mendikbud No. 4 Tahun 2020, Pelaksanaan kebijakan pendidikan dalam masa darurat penyebaran corona virus disease (Covid-19).

Watson, G., \& Sottile, J. (2010). Cheating in the digital age: do students cheat more in online courses?. Online Journal of Distance Learning Administration, 13(1).

Widyaninggar, A. A. (2015). Pengaruh efikasi diri dan lokus kendali (locus of control) terhadap prestasi belajar matematika. Formatif: Jurnal Ilmiah Pendidikan MIPA, 4(2), 89-99. https://doi.org/10.30998/formatif.v4i2.143.

Yokoyama, S. (2019). Academic self-efficacy and academic performance in online learning: A mini review. Frontiers in Psychology, 9(JAN), 1-4. https://doi.org/10.3389/fpsyg.2018.02794.

Yu, H., Glanzer, P. L., Sriram, R., Johnson, B. R., \& Moore, B. (2017). What contributes to college students' cheating? A study of individual factors. Ethics and Behavior, 27(5), 401-422. https://doi.org/10.1080/10508422.2016.1169535. 